\title{
Organic agriculture: opportunities and challenges
}

\author{
Paul Kristiansen*, University of New England, Australia, Acram Taji, University of New England, \\ Australia and John Reganold, Washington State University, USA \\ *Dr Paul Kristiansen, School of Rural Science \& Agriculture, University of New England, Armidale, New South Wales 2351, \\ Australia. Tel: +61 26773 2962, Fax: +6126773 3238, Email: paul.kristiansen@une.edu.au
}

\begin{abstract}
The tradition in agriculture has been to maximize production and minimize the cost of food with little regard to impacts on the environment and the services it provides to society. As the world enters an era in which global food production is likely to double, it is critical that agricultural practices be modified to minimize environmental impacts even though many such practices are likely to increase the costs of production. (Tilman 1999)
\end{abstract}

\section{Introduction}

The organic movement may have gained a place in the spotlight of the mainstream media now, but it has not been like that for long. Since the 1950s, organic farmers operating at a grass roots level have devised, tested and shared production methods. They have codified a set of ideals into a pioneering best practice agricultural management system that addresses multiple community values. Niche markets have gradually been created, commonly based on trust and goodwill (formal certification did not begin until the 1960s and 1970s), and often using novel direct marketing strategies such as box schemes and community supported agriculture. After many years of consumers having to hunt around for their organic produce from several suppliers, perhaps directly from the farmer, the task is now a lot easier with specialist food shops and organic shelf space in supermarkets, in the industrialised world at least. Global links have been forged in all continents as organic agriculture has been seen to be an effective rural development option.

Although the movement is still regarded with some scepticism (e.g. Trewavas 2001, Kirchmann and Ryan 2004, Trewavas 2004), the concept of organic farming has strong marketing appeal, growth forecasts are almost all positive and it has been suggested that the 'movement' is now an 'industry' (Cornish and Stewart 2002). Organic agriculture is one of the fastest growing agribusiness sectors in the world, with double-digit annual growth in land under organic cultivation, value of organic produce and number of organic farmers. There are about 26 million hectares of organic farmland currently and the global market value of organic goods in 2003 was US $\$ 25$ billion per year (Willer and Yussefi 2005, see also Chapter 10), about 2\% of the US $\$ 1.3$ trillion per year in global agricultural production (Wood et al. 2001). Furthermore, each year brings new peer-reviewed research showing the strengths and weaknesses of organic agriculture (see Chapter 15), a sign of growing interest by academics and funding bodies. 
Despite the generally positive outlook, the organic movement faces several hurdles as it expands internationally. A recent review of organic farming listed several challenges facing organic agriculture (Halberg et al. 2005a) including:

- ecological justice;

- animal welfare;

- fair trade;

- supply chain development;

- productivity limitations; and

- regional adaptation and global harmonisation for standards.

Many of these can be seen through one lens, the need to remain dynamic. New issues and changed circumstances require on-going adaptation by the organic movement. To embrace these wider concerns, the organic movement needs to maintain flexibility in the regulations and the processes used to implement the regulations. As additional client countries and novel products apply for organic certification, new processes and production guidelines will be required in many cases (Woodward and Vogtmann 2004, Köpke 2005). After a period of expansion since the 1980s, a stage may have been reached where the organic movement is being confronted by limits in its ability to initiate change without itself changing (see Chapter 9). This tension has become explicit in the corporatisation of organic agriculture (Ikerd 1999, Guthman 2000, Sligh and Christman 2003, see also Special topic 3 for further discussion).

The need for adaptability is increased by global marketing chains and electronic media that can now provide fast transfer of products and ideas. New commodities are continually being developed by producers and embraced by consumers. Even food scares can alter buying patterns very rapidly. In this dynamic marketing environment, organic agriculture is being moulded by socioeconomic factors well beyond its control (see Chapter 17).

But the process of reviewing and reflection within the organic movement is not new. The movement has continually transformed itself as it has grown and matured in Europe from the 1920s to the establishment of international groups, such as the International Federation of Organic Agriculture Movements (IFOAM) in the 1970s, and the export of organic farming beyond Europe has seen organic groups around the world create locally adapted networks and solutions to certification, production and supply problems (Reed 2003, see Chapter 1). Along with new territory, organic production has captured new industries, necessitating the development and integration of completely new standards for forestry, aquaculture and textiles (IFOAM 2005). Another challenge is the controversial role of contamination by genetically modified organisms (GMO). However, despite strong opposition to GMOs throughout the movement, senior members of the organic movement are beginning to look at the suitability of zero tolerance (Clay 2003).

Without robust and comprehensive social and environmental accounting, the broad question could be asked: Is modern conventional agriculture just an expensive indulgence for affluent countries? Although agricultural and food production in the modern world has successfully increased overall yields and overcome many biophysical limitations, it has also been a destructive force for the environment (Millennium Ecosystem Assessment 2005), excessively consuming key resources, such as soil and water mostly, underutilising 'waste' streams and thus polluting other resource bases (Box 18.1). It is in this context of current global land use that organic farming systems should be evaluated. Kasperczyk and Knickel (see Chapter 12) found that organic agriculture provided several environmental benefits including lower pesticide pollution, enhanced biodiversity and ecological services, improved soil health (i.e. organic matter, biological activity, nutrient cycles, erosion risk), and strong links between organic farmers and nature conservation activities (also see Lohr 2005). However, definite conclusions cannot be made for many places around the world because of the absence of data. 


\section{Box 18.1 Selection of findings highlighting the long-term impact of agriculture and related activities on natural resources (Wood et al. 2001 and Millennium Ecosystem Assessment 2005)}

More land was converted to cropland since 1945 than in the 18th and 19th centuries combined, and now about one-quarter (24\%) of Earth's terrestrial surface has been transformed to cultivated systems.

Moderate to severe soil degradation occurs on $52 \%$ of global agricultural lands.

Human activities now produce more biologically usable nitrogen than is produced by all natural processes combined.

More than one-half of all the manufactured nitrogen fertiliser (first produced in 1913) ever used on the planet has been applied since 1985.

The flow of nitrogen to the oceans has doubled since 1860 .

Water withdrawals from rivers and lakes for irrigation, household and industrial use doubled in the last 40 years.

Humans now use between $40 \%$ and $50 \%$ of the freshwater running off land to which most of the population has access.

Total food production increased by about two-and-a-half times while the number of people in the world doubled from 3 billion to 6 billion between 1960 and 2000 .

Despite the growth in per capita food production since the 1970s, an estimated 852 million people were undernourished in 2000-2002, up 37 million from 1997-1999.

The number of species on the planet is declining and the species distribution is becoming more homogenous.

Genetic diversity has declined globally, particularly among cultivated species.

Water and air pollution were more problematic in organic farming because of the reliance on manures, and Kasperczyk and Knickel also raised a common concern that economic pressures to maximise short-term production may compromise the beneficial aspects of organic agriculture.

Chapter 4 began with two important points that are worth restating here. First, organic growers are not homogeneous. Some farmers use 'substitution-based' approaches and are seeking premium prices for their goods. Others are 'subsistence' producers using organic methods by default. Between these groups are a range of philosophically committed organic growers who are more motivated by environmental and health issues. Second, Letourneau and van Bruggen (see Chapter 4) question the use of 'simplified' terms, such as organic and conventional, preferring instead to focus on specific management practices and agroecological mechanisms. By focusing on actual practices and processes within farming systems, it is expected that the observed effects of certain organic practices can be more clearly quantified and interpreted. The finding can also be generalised for other locations, crops or farming systems.

In this Chapter, key conclusions from earlier chapters have been compiled and summarised. Many themes were consistently reiterated in the various chapters, confirming the importance of those themes across a wide range of settings. Rather than speculating on the future of organic agriculture and its possible impact on world food security and the environment, this 


\section{Box 18.2 Benefits and opportunities for organic agriculture}

Provision of ecological services, such as crop protection, yield stability and system resilience.

Reduced chemical residues in food and the environment.

Few strongly negative environmental impacts.

Economic performance is often equivalent to conventional farming.

High standards of animal welfare.

Reliable and credible standard-setting processes and certification schemes.

Dynamic review of policies and standards.

Strong consumer demand and brand recognition.

Indigenous knowledge is valued.

Potential for cooperative rural and regional development.

concluding chapter is more concerned with documenting and reviewing current knowledge, identifying strengths and weaknesses, and applying that information to the immediate challenges ahead. Opportunities for supporting the continuing development of the organic movement through cross fertilisation of technologies and conceptual approaches in the areas of supply chains and farming systems are discussed.

\section{Opportunities and challenges}

Organic farming has attracted considerable attention from those who see it as a panacea to those who see it as ideological nonsense. A more humble responsibility for the organic movement may be to serve as role model for a farming system in which values other than financial are cultivated (see Chapters 8 and 14). Organic farming asks how we ought to relate to each other and our natural environment (see Special topic 3). The values of the organic movement are not esoteric, but are based on observation and common sense: treat livestock well, use resources sparingly, use the least harmful method, nature is inherently valuable and so on. Food security depends upon personal relationships of integrity and trust among farmers, farm workers, suppliers, consumers and others up and down the agricultural supply chain (see Special topic 3), and integrity and trust have been fundamental to organic agriculture's success.

There are many other role models across the spectrum of agricultural systems, such as conservation tillage, permaculture and traditional farming systems, but organic farming has emerged as one of the best known alternative farming systems developed in response to the shortcomings of mainstream agriculture. Many of the key benefits and opportunities for organic agriculture (Box 18.2) are suitable areas for the organic movement to show leadership and innovation, including assurance and auditing procedures, rural and regional development and low cost agricultural systems relying on biological and ecological processes.

A range of challenges that were highlighted in other chapters are listed in Box 18.3. Some of these challenges are in conflict with each other (e.g. global harmonisation versus local adaptation) and some challenges are also opportunities (e.g. dynamic review of policies and stand- 


\section{Box 18.3 Challenges for organic agriculture}

Maintaining sustainability in the global economy: balancing organic principles with commercial imperatives.

Maintaining flexible organic standards and certification processes to address issues such as:

- nature conservation and regeneration;

- equitable, affordable and flexible access to certification services;

- responsible labour relations and land tenure arrangements;

- animal welfare;

- new inputs such as 'natural' biocides, soil amendments and GMOs; and

- incomplete or unscientific basis for including/excluding materials from organic standards.

Pursuing international harmonisation of standards and certification.

Developing locally applicable agronomic solutions to production constraints, such as weeds, animal health and soil fertility.

Expanding research activities in many disciplines (particularly beyond Europe and North America) and foster the integration of knowledge.

Preserving food quality while trying to increase productivity.

Educating and training at all levels to build capacity, infrastructure and networks.

Inadequacies in regulatory and marketing structures (e.g. labelling).

Excessive consumer prices and inconsistent quality and availability.

Establishing and maintaining credibility and professionalism.

ards). Specific local agronomic requirements can also create pressure to modify standards. For example, phosphorus $(\mathrm{P})$ fertilisers allowed under the certification standards are unable to supply adequate $\mathrm{P}$ in the inherently deficient soils in parts of southern Australia. Consequently, the restriction on citrate-soluble superphosphate has been questioned (Penfold 2000).

The question of whether organic food is better for human health than conventional food is central in the minds of organic consumers (see Chapter 11). Yet the research indicates that no definitive nutritional differences have been found (see Chapter 13). Reviews in several countries all concluded that there is no evidence for any direct health benefits associated with the consumption of organic foods. These reports also concluded that there were no health risks associated with organic food. Differences were reported for a range of nutritional characteristics, but there is no consistency across the literature.

Despite the lack of nutritional differences in the comparative review, examination of large data sets showed that organically grown foods consistently had about one-third of the pesticide residues in conventionally grown foods (Baker et al. 2002). There are also numerous examples in the broader research literature that showed links between food production methods and food quality, and that these differences are large enough to influence consumer health (see Chapter 13). By gaining an understanding of the relationships between production methods and food quality, improvements can be made in the quality of produce from a system, whether it is organic or conventional. However, there are limitations in the experimental approach of some of the studies, such as confounded designs, inadequate time frames and not targeting aspects where differences are most likely. Brandt and Mølgaard note the scientific 
evidence shows that only organic methods have demonstrated the ability to improve both yield and nutritional quality simultaneously, and that organic principles effectively protected against 'mad cow disease' (bovine spongiform encephalitis).

The yields in organic agriculture may be equivalent to or better than conventional agriculture, although often they are not, simply because of inadequate plant available nutrients, weed infestation, non-cash phases in the crop rotations or inexperienced management (see Chapter 1). Yield performance is very location and management specific and many underlying drivers (e.g. soil carbon, weed seed banks) of yield have long responses times (Martini et al. 2004, see Chapter 15). Some researchers have also highlighted the value of alternative agroecological criteria such as resilience and stability (Trenbath 1999, Lotter et al. 2003). Although organic agriculture causes less pesticide contamination in food, people and the environment, it is premature to claim that organic agriculture is completely environmentally sustainable (see Chapter 12). In particular, some soil nutrients have negative budgets in certain organic cropping systems, causing a depletion of soil reserves of that nutrient (see Chapter 1).

\section{Looking to the future}

Organic agriculture will always be operating in a broader context of powerful market forces controlling the flow of inputs and outputs including intellectual property. Social expectations about agricultural production systems and consumer preferences also interact closely with the market place creating an uncertain future for organic growers and traders. Lockie et al. (see Chapter 11) are cautious about making predictions about the size of the organic market into the future. Predictions are difficult because of changing global demographics and dietary tastes, as well as the knowledge that past successful marketing strategies may not remain effective.

The same caveat should apply to predictions about global organic expansion and the consequent inability to feed the world (Avery 1997). The challenge of feeding the world applies to any modern farming system, as the Millennium Ecosystem Assessment Synthesis (2005) report reminds us: global food production is adequate, yet poverty and environmental destruction persist. Whatever agricultural system, or hybrid of systems, is used to provide food and fibre for the international community, it will presumably be supported by democratic governments, the business community and by farmers and consumers, and problems will be solved progressively. A range of feedback mechanisms is likely to evolve to maintain equilibrium between production and sustainability:

- 'mainstreaming' the 'alternative', possible mass market opportunities;

- preventing excesses through regulation (e.g. onerous compliance for registration of inputs); and

- supporting transition through enabling policies, e.g. subsidies, harmonisation, brokering and collaboration, research funding (Thirsk 2000, Pretty et al. 2003, Stoneham et al. 2003).

Organic farming systems have not been optimised over many decades by large inputs of time and money for research, industry development and extension services in the same way that conventional farming systems have. Therefore, the ability of the organic movement to provide a broad solution to global food and fibre production problems is limited in current circumstances. Although organic farming systems have some well recognised benefits, widespread adoption of organic agriculture as the sole method of farming is unlikely in the shortterm to medium-term, even in the most progressive countries in Europe. Modelling of large-scale conversion to organic agriculture at realistic rates (10-20\%) indicates that such 
conversion would be unlikely to cause adjustment problems to the agricultural sector, for example, as a result of significantly lower yields (Halberg et al. 2005b, see Chapter 10).

The report of the Millennium Ecosystem Assessment (2005) lists several general strategies for promoting more sustainable land use that are very applicable to organic agriculture. These strategies include creating appropriate governance and marketing structures, overcoming social and behavioural constraints, encouraging investment in the development and diffusion of suitable technologies and fostering a robust knowledge and skills base. Several more specific policy options were also recommended:

- removal of production subsidies that have adverse economic, social and environmental effects;

- investment in, and diffusion of, agricultural science and technology that can sustain the necessary increase of food supply without harmful tradeoffs involving excessive use of water, nutrients or pesticides;

- use of response polices that recognise the role of women in the production and use of food and that are designed to empower women and ensure access to and control of resources necessary for food security; and

- application of a mix of regulatory and incentive-based and market-based mechanisms to reduce overuse of nutrients (Millennium Ecosystem Assessment 2005).

The importance of recognising the role of women is reinforced by Lockie et al. (see Chapter 11) who state that gender, not education or income, is the most important demographic factor influencing patterns of organic consumption, because women report purchasing organic foods more than men.

There is a diverse range of emerging and existing technologies and conceptual approaches that are compatible with organic agriculture, and where organic agriculture has existing strengths, such as adult education and soil microbiology (Figure 18.1). These technologies can provide the organic movement with opportunities to improve productivity, overcome marketing constraints, reduce harmful environmental and social impacts and maintain a progressive, constructive stance in relation to research, development and education. The following discussion about the ongoing role of the organic movement in agriculture is based on the broad, nonexclusive topics, supply chains and farming systems, identified in Figure 18.1. These topics each have several themes listed as examples; however, these lists are not intended to be exhaustive.

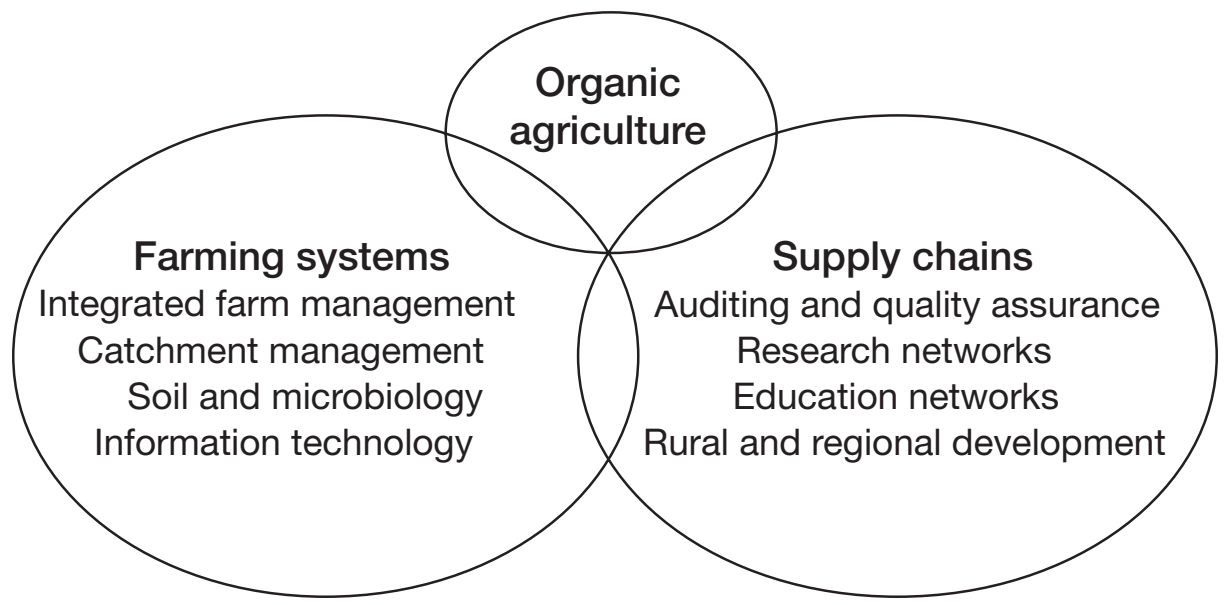

Figure 18.1 Technologies and conceptual approaches relevant to organic agriculture. 


\section{Supply chain technology}

There are numerous parts of an agricultural supply chain, with many stakeholders. A consequence for organic agriculture is that there are many areas that need to be established, modified and strengthened. Major areas of interest are:

(a) the creation and expansion of knowledge networks for research and education;

(b) continuing revision of the organic standards and certification processes; and

(c) a clearer role of organic farming in rural and regional development.

\section{Knowledge networks - research}

To enable organic agriculture to grow and mature several supporting mechanisms are needed. Such mechanisms include on-farm and collaborative research, teaching at a wide range of competencies from farmer field days to doctoral studies (see Chapters 15, 16 and 17), a comprehensive and reliable knowledge base, widely accessible information flow lines and a diverse pool of skilled people. Much of this process is under way, but considerable effort is still required.

Research is vital for sectoral development as it allows new knowledge to be developed, such as increasing yield and productivity, quantifying environmental and social impacts, minimising adverse effects and maximising benefits (see Chapter 15). Research and development in organic farming is normally constrained by scarce funding from governments and large commercial stakeholders, and smaller commercial players are generally unable to allocate funds for research and development (Wynen 2003). There are no fundamental essential barriers to establishing cross-disciplinary research collaborations, but various practical and structural barriers exist including access to funding, cost of larger long-term trials and project coordination difficulties (see Chapter 15).

Despite criticisms about a lack of objectivity in organic research, almost all research activities are inherently value-laden, with choices routinely being made about subject matter, funding sources, treatments to apply and methodologies to follow (see Chapter 15). No single research strategy is adequate to address the needs of the global organic agriculture movement. Instead, there are several issues to consider. A balance needs to be achieved between reductionist and holistic approaches (combining disciplinary and systems thinking), between short-term and long-term trials and between multidisciplinary and single discipline projects. The process of data collection, synthesis and interpretation should take place at all levels from the 'plots and pots' of experimental trials to whole farms, and from catchments and bioregions to local and global markets. Action, participatory and on-farm research approaches provide a range of options for encouraging cooperation between project stakeholders, although their effective use depends on the interests of the stakeholders and facilitation skills of the project leaders (see Chapter 15).

Relatively new organisations such as the International Society of Organic Agriculture Research, Colloquium of Organic Researchers in the United Kingdom (UK) and The Organic Center, as well as the Scientific Committee for Organic Agriculture Research in the USA demonstrate that the organic movement is moving to another level of sophistication in pursuing research. Together with the growing number of private and government research centres being established (see Chapter 15) and universities offering study programs in organic farming (see Knowledge networks - education), there is an opportunity to produce more research, produce better quality research and to reduce research overlap by increasing collaboration.

It is common (and logical) for researchers to highlight the need for further research in their discipline, and that is true of all chapters in this book. Some specific areas where research has been absent or less intensive include:

- environmental impacts (see Chapter 12); 
- $\quad$ social dynamics (see Chapters 9, 11, 14, 16 and 17);

- animal husbandry (see Chapters 7,8 and 9);

- determining goals for breeding and selection and maintaining genetic diversity, including livestock rare breeds and heirloom crop varieties (see Chapters 4, 5 and 6); and

- economic management, specifically market access, price stability and cash flow (see Chapter 10).

\section{Knowledge networks - education}

Much of the education and training in organic agriculture has taken place in apprentice-type situations with farmers as teachers and young people as learners in a practical, hands-on learning environment. This has evolved into the global tradition of strong farmer groups in the organic movement (see Chapter 16). Some of this experience is being captured through farm visits and other teaching methods, and linked with educational theory to develop courses in organic agriculture in universities. Like research into organic agricultural systems, there is usually a lack of institutional support in most countries. The only consistent exceptions are courses offered by organic grower groups. International tertiary education links have been established within European countries and between Europe and other regions such as North America and Australia. Many universities now offer individual subjects, majors and full courses in organic agriculture, providing a valuable pool of agronomists, veterinarians, extension officers and other specialists with specific training in organic principles and practices (see Chapter 16).

Organic farms are inevitably complex places, with greater biological and enterprise diversity than conventional farms (see Chapters 12 and 17). There are many competing factors to manage and decision making is challenging. In addition, these is less chance of contacting a commercial or government agronomist and seeking advice, though this is changing as the upstream end of the supply chain grows with 'biofertiliser' products proliferating at agricultural field days and in industry magazines. Sound management skills and independence are therefore vital. These preconditions for successful organic farming - complexity and independence - are important because they influence how organic education can be taught (see Chapter 17). In developing a curriculum, a course should 'help prepare students to deal with the complexity and uncertainty they will face in working for sustainable agriculture and food systems for the future' (see Chapter 16). In several tertiary courses on organic agriculture there is an expectation that organic agriculture students will be able to cope with student-centred learning, perhaps on a problem-based learning or case study project (Lieblein et al. 2005). Student-centred learning is preferred because it increases the amount of information processing, as opposed to simple memorising, producing deeper learning (see Chapters 16 and 17). There is also an emphasis on experiential learning, preferably involving considerable interaction with organic farmers on their farms. Although not exclusively relevant to organic agriculture, integrated teaching approaches have good conceptual alignment with integrated (organic) farming approaches as both foster skills in managing complexity and independent critical thinking (see Chapter 17). The teaching approach suggested by Sriskandarajah et al. (see Chapter 16) and used in many agricultural courses around the world has limitations, including the costs involved with running field trips for students, the facilitation skills required to deliver experiential-based curricula effectively and the inflexible administrative structures of tertiary institutions.

The conceptual models presented in the chapters on social responsibility, tertiary education and farmer education show uncanny harmony (Table 18.1). Despite considerable disciplinary overlap, this convergence of models was not as a result of similar theoretical sources (the relevant citations are different in each chapter). Instead, the models highlight the simple 
Table 18.1 Conceptual models presented in the chapters on social responsibility, tertiary education and farmer education

\begin{tabular}{|l|l|}
\hline Conceptual model & Source \\
\hline Learning $=$ regulation $\times$ cooperation & Pyburn et al. $($ see Chapter 14) \\
Knowledge $=$ information $\times$ processing & Sriskandarajah et al. $($ see Chapter 16) \\
Knowledge creation $=$ knowledge acquisition $\times$ participation & Seppänen and Francis (see Chapter 17) \\
\hline
\end{tabular}

dichotomy of 'thinking and doing' (matter and energy) as the common factors required to produce an action or outcome, in this case learning. As the manager of a complex agroecosystem, a capable organic farmer or student will need to be able to think and do simultaneously, compile and integrate information from different sources, make and implement decisions, review past performance and revise future strategies. A good conventional farmer would do the same, but he or she would have greater recourse to finding people to do the thinking for them - the commercial agronomists, long established marketplaces and supply lines, a shared history of production methods within a district, the industry magazines and so on. However, organic growers have traditionally not had those options, and acquiring generic, ready-made knowledge is likely to be insufficient (see Chapter 17). In addition to the lack of information and infrastructure, organic farmers are obliged to achieve production goals with less reliance on externally inputs and to pursue non-economic values such as maintaining and creating social and ecological capital. These demands create a high level of biological diversity and managerial complexity that, again, conventional growers may choose not to pursue, instead focusing simply on maximising yields and profitability.

\section{Auditing and quality assurance systems}

The organic standards setting and certification systems were developed to ensure that organic produce is genuine, potentially the most important strategy in the marketing of organic goods (see Chapter 11). Three main regulatory challenges facing organic agriculture are:

(a) international harmonisation and the tensions between regulatory agencies;

(b) ensuring stringency in assurance systems for global consumers while also allowing for locally appropriate adaptations; and

(c) and ensuring equitable access to organic certification systems, particularly in developing countries (see Chapter 9 and Special topic 3).

An underlying theme in such challenges is one of balancing competing needs.

The organic movement now has many more stakeholders than in the mid-1980s, and these voices all deserve to be heard in such an overtly democratic movement (e.g. IFOAM 2005). Although it will take considerable time and cooperation, international harmonisation is a necessary and possibly inevitable process (see Chapters 9 and 10). The International Task Force on Harmonisation brings regulatory agencies together to compare each others' systems and evaluate various other programs and models (see Chapter 9), but countries without their own standards will be at a disadvantage (see Chapter 10) and separate national disputes will continue to hinder progress (Lotter 2003, Alexandra and May 2004).

In Chapter 14, Pyburn et al. advocate a mixture mechanism to stimulate and provide incentives for social responsibility throughout the supply chain. To achieve more than superficial change in social responsibility, a learning approach can provide a hands on, direct experience for people and groups affected by social issues in agriculture. Standard setting needs to be based on support by several stakeholders in the organic food chain, including collaboration between organic certifiers and other social certifiers, such as FairTrade Labelling Organizations International and the International Labor Organization. Internal Control Systems have 
been used for group certification in developing countries (see Chapters 9 and 14). Various stakeholders including farmers and certification agency representatives meet for discussions, out of which comes a new understanding for farmers (e.g. more technical knowledge about organic farming, expanded personal networks) and agency staff (e.g. more knowledge about local constraints for organic production), and ultimately refined standards and certification methods are produced. Ideally, the standards are temporary and always subject to revision, and are the outcome of a cooperative learning process rather than an instrumental process dominated by a few powerful interests (see Chapter 14).

Strategies to maintain and strengthen the effectiveness of organic certification have been identified (Consumers Union 2003, see also Chapters 7, 9, 10 and 14):

- internal control systems as a tool for smallholder group certification;

- participatory guarantee systems in formalised regulatory systems;

- complementary regulatory structures to provide assurance across sectors and regions;

- transparent auditing and verification systems; and

- approval of allowable inputs based on peer-reviewed science.

\section{Rural and regional development potential}

More people depend on agriculture in developing countries than in the industrialised countries of Europe, North America and parts of Asia-Pacific. Subsistence is often the first priority, after which goods for the market can be bartered or sold for cash. In this scenario, organic agriculture, or parts of it at least, may be a useful development tool. Just as integrated teaching methods suit organic farming courses, the emphasis on integration and multidisciplinarity in organic farming readily complements participatory approaches to development, and indigenous intellectual and material resources are often compatible with organic farming (see Special topic 5).

There are many examples of the beneficial role of organic agriculture in sustainable development in poorer rural areas (e.g. Parrott et al. 2005, Tafuna'i 2005, see also Chapters 7, 9, 14 and Special topic 5), although its effectiveness has been poor in many places partly as a result of a lack of local demand for certified organic products and limited export potential due to compliance problems (e.g. cost and disease restrictions) (see Chapters 7 and 14). Agricultural development projects should start from existing local practices, yields and knowledge and not from the promises of a new technology. Extension and support should be a mixture of technical, social and cultural approaches suited to the learning styles of the target group. Where possible, activities should expand beyond an initial disciplinary subject approach using a topdown extension method into an integrated approach with a participatory development process. These guidelines would be relevant for extension and research activities with farmers in any country and are not unique to development settings (see Special topic 5).

\section{Farming systems technology}

To develop a successful farming system requires a combination of personal skills, suitable land and a market for the produce. In particular, successful on-farm production requires careful consideration of local conditions. Although the organic standards and the collective knowledge of organic farmers can be used for guidance, some experimentation will be required to manage each unique combination of weeds, pests and soil imbalances. For example, internal parasites in livestock pose a major problem for organic and low-input sheep graziers around the world and conventional graziers are facing resistance to chemical drenches (Welsman 2001, Keatinge et al. 2002, Githiori et al. 2003). The potential for collaborative research into non-chemical means of managing livestock parasites could involve grazing strategies, phytomedicines, breeding and novel veterinary treatments (e.g. homeopathy) (see Chapters 6, 7 and Special topic 2). 
In some highly weathered soils and semi-arid environments, essential soil nutrients, such as $\mathrm{P}$, are likely to be limiting and the options permitted under current organic standards may be inadequate and considered unsustainable (Kirchmann and Ryan 2004, see also Chapter 2). Furthermore, in some countries, the distance between farms and the primary sources of key inputs is large and the range of inputs becomes severely restricted (Buresh et al. 1997).

Given that soil fertility is central to organic production, this aspect of negative nutrient budgets should not be dismissed too easily because the question of $\mathrm{P}$ has been raised in a variety of settings in Germany (Lampkin 1990) and the UK (Gosling and Shepherd 2005) and, away from temperate Europe, in Sub-Saharan Africa (Pender and Mertz 2005) and Australia (Penfold 2000). Based on current data, for some places in the world, rock phosphate will not be able to provide plant-available P to the soil quickly enough (see Chapter 2). Biological, chemical and physical methods of increasing the effectiveness of rock phosphate are being investigated, with a focus on the following factors:

- mineral properties: reactivity, particle size, surface area;

- soil factors: $\mathrm{pH}$, titratable acidity, $\mathrm{P}$ and calcium (Ca) availability and retention, sand content, biological activity, organic matter content, moisture, temperature; and

- plant factors: P and Ca demand, root structure, rhizosphere $\mathrm{pH}$ (see Chapter 2).

However the effects are often neither significant nor important agronomically (Ryan and Ash 1999, see also Chapter 2). Like collaborative research into sheep parasites, there are many stakeholders interested in improving soil $\mathrm{P}$ availability.

Despite some serious but localised problems, organic farms are either already in practice or are possible to establish in many agricultural settings (see Chapter 4). The constraints that exist are often similar to those faced by conventional farmers (soil fertility, plant and animal health) and there is considerable common ground in rectifying issues such as improved P solubilisation and non-chemical parasite control in livestock. Some of the agricultural technologies that organic growers can and do use are now discussed.

\section{Integrated farm management}

Many different schemes have been established to devise and promote more efficient, less environmentally damaging methods of agricultural production. A myriad of these integrated management schemes can normally be identified by their acronym, for example Integrated Pest Management (IPM), Low External Input Sustainable Agriculture (LEISA) and Environmental Management Systems (EMS). The common element among these concepts is that of achieving production goals by integrating a diverse range of strategies in a planned but flexible way. These approaches have clear links with organic principles of diversity and rely on ecological processes to aid production. In regard to managing crop protection, Letourneau and van Bruggen (see Chapter 4) have distilled three important principles related to managing invasive species ecologically: prevention of colonisation or establishment, population regulation through biological processes and curative interventions. Weed and animal health management would be expected to operate on similar principles (see Chapters 1, 7 and Special topic 1).

As discussed, there is potential to learn from developing countries, such as those starting to adopt organic farming methods. Indigenous agricultural knowledge systems offer many innovative ideas for low-input farming that could be adapted for use on organic farms in other countries (Nyeko et al. 2002, Vogt et al. 2002, Cools et al. 2003). The use of the plant neem (Azadirachta indica) is an especially well-recognised example of indigenous knowledge.

Organic plant and animal breeding uses classical methods of crossing and selection based on desirable traits (see Chapters 4, 5 and 6). The traits required for an organic ecosystem are often different to traits for conventional farm ecosystems, thus requiring organic-specific variety trials to determine performance. In plant breeding, various traits such as early vigour 
and leaf orientation are used because of their contribution to ecological crop protection (see Chapters 3 and 5). Research and commercial opportunities exist for producing new lines of organic seed varieties. Several large European seed companies have begun marketing organic seed; however, several small organic seed merchants have also become established where local demand for organic seed has made it viable (Neeson and Howell 2003). One step down the supply chain is seedling production, mostly for use on organic herb and vegetable farms. This sector of the conventional nursery industry is highly regulated and mechanised and therefore very cost efficient. Modifying such systems to suit organic methods, or developing alternative methods, is a priority because of the planned ending of derogation rules that allow organic growers to use conventional inputs when suitable organic supplies do not exist (Pearce et al. 2000, Greer 2002, White 2005). The recent growth in the organic seed and seedling sector indicates the flow-on demand along the supply chain from farmers seeking local cultivars suited to organic conditions (see Chapter 5).

Livestock, especially cattle, have a long and essential part in the history of organic farming (Lampkin 1990). Their ability to perform cost-effective multiple functions is world renowned for draught, weeding, milk, hides, meat and several types of organic fertiliser, such as manure and blood-and-bone. Unlike crops, animals are not simply components of a farming system. Animals are also sentient creatures and therefore can be expected to have certain moral rights (see Chapter 7). In biodynamic agriculture, the cow has a special place as provider of horns and other organs in the manufacture of various compost-based and manure-based soil conditioners (see Special topic 2). Although organic principles recognise the importance of having a natural life, natural living does not automatically imply good welfare. Key health and nutrition requirements also need to be met. Nevertheless, organic animals have similar health and welfare experiences compared to conventionally managed animals (see Chapter 8 ).

The role of catchments (or watersheds) in providing ecological services to agriculture has often been underrecognised, although there is growing interest among mainstream researchers in evaluating methods of integrating farmland, natural vegetation, water bodies and other landscape features (Stirzaker et al. 2000, van de Ven et al. 2003). In addition to work on the ecological services provided by diverse landscapes (see Chapter 4), research on systems design has investigated perennial systems, farm layout, crop rotations, water management and so on (Doing 1997, Kuiper 1997, Vereijken et al. 1997, see also Chapter 1). In many cases, the issue of adoption is a concern, especially if compliance is complex or costly, or where the benefits are difficult to discern (Ridley 2005).

\section{Soil biology and microbial ecology}

The importance of biology in maintaining soil health and fertility has always been appreciated by the organic movement. It is one of the most fundamental aspects of how soil is conceptualised in organic agriculture (IFOAM 2002). For many years this was a key feature distinguishing organic farming from conventional farming, where the latter system was almost entirely focused on chemical and physical properties of soil (see Chapter 2). However, with growing interest in the biological aspects of soil fertility, there are technologies available that can help measure biological activities and composition and these tools are very useful for evaluating the performance of different farming systems or different treatments within a farming system. Studies in molecular microbiology and soil microbial diversity have the potential to improve our understanding of complex nutrient cycles (see Chapter 2). Analytical techniques using, for example, phospholipid fatty acids and substrate-induced respiration provide the ability to study microbial community structures and population dynamics, factors that can be related to soil properties such as nutrient availability, structure and pathogenicity (Carpenter-Boggs et al. 2000b, Svensson and Pell 2001, Harris 2003, Steenwerth et al. 2003). 
Although microbes have been shown to improve various soil quality parameters in different soil types and environments, yield improvements are not always observed and generally speaking the addition of significant volumes of organic matter is essential to increase the size or activity of the soil biological community (Edmeades 2003, see also Chapter 2). Soil organic matter content is especially difficult to increase in some environments; for example dryland, semi-arid environments with high temperatures and low precipitation, threatening the sustainability of organic farms in such areas (see Chapter 2). Increasing soil organic matter in organic agriculture is restricted by:

(a) slower accumulation of organic matter inputs compared with conventional farms as a result of lower crop yields and less intensive animal production systems;

(b) organic leys decomposing more quickly because of lower carbon to nitrogen ratios; and

(c) tillage required for weed control (Gosling and Shepherd 2005).

The application of microbial ecology (e.g. soil food webs) to agricultural production systems has provided a useful framework for understanding a range of soil processes including nutrient mineralisation and pathogen control (Ingham et al. 1985, Drinkwater et al. 1995, Wardle et al. 1999, Manici et al. 2004). Several specific strategies for increasing microbial activity have been developed such as effective microorganisms, compost teas, biodynamic preparations and so on (Sena et al. 2002, Chen et al. 2003, Compost Tea Task Force 2004, see also Special topic 2); however, many have not been rigorously evaluated and the mechanisms of action remain unclear (see Chapter 2).

In addition to maintaining soil health, microbes are also important in converting manures, crop residues and other organic materials into composts, humus and plant available nutrients (Welbaum et al. 2004, see also Chapter 2 and Special topic 2), providing biological control of certain pests and diseases (Trejo-Estrada et al. 1998, Brimner and Boland 2003) and decomposing crop residues in the paddock (Vazquez et al. 2003).

A general objective in biodynamic soil management is to produce a compensating, stabilising influence on growth in which extremes are avoided (Goldstein and Barber 2005, see also Special topic 2). Biodynamic farmers utilise microbial activity in a unique way through the use of manure-based preparations (Raupp 1999) and positive agronomic and economic outcomes have been reported many times for biodynamic systems in different circumstances (e.g. Reganold 1995, Mäder et al. 2002). Attempts to measure the effect of biodynamic preparations are often limited by factors such as insufficient time under biodynamic management and confounding with whole-system effects (Carpenter-Boggs et al. 2000a, see also Special topic 2).

\section{Conservation tillage}

Tillage has been a necessary part of agriculture for centuries and it remains a key tool in organic farming. Important functions performed by tillage are seedbed preparation, incorporation of soil amendments, increasing soil mineralisation, crop protection and, most commonly, weed control. However, over-reliance on tillage, rather than tillage itself, is problematic in several situations, such as erosive, compacted, dry or wet soils and on sloping ground. The consistent lack of negative effects by organic farming on soil structure and microbial activity suggest that organic management practices are contributing to a resilience in the soil (see Special topic 4).

Many of the positive soil and water conservation benefits from conservation tillage practices can be lost in organic farming systems as a result of the reliance on multiple inversion tillage operations for seedbed preparation, incorporation of cover crops and weed management that can degrade soil quality (see Chapter 2). High-residue reduced-till systems using commonly accepted grass-legume mixtures, permanent soil cover and very limited strategic 
tillage offer the potential to synchronise nutrient supply with crop demand and multiple nonnutrient effects, including weed suppression, soil aggregation, resistance to erosion, biological pest management, and water infiltration and availability (see Special topic 1).

Successful examples of organic and non-chemical no-tillage systems have been demonstrated. These have all been short-term systems located in areas with long warm seasons (see Special topic 1). On the contrary, temperate organic no-till systems and permanent organic notill systems have specific challenges due to slower cover crop growth and breakdown, different weed types and limited control options (see Special topics 1 and 4). Difficulties faced in organic no-till systems include producing adequate cover crop growth to perform agroecological functions properly, lack of reliable implements for effectively terminating the cover crop to prevent regrowth, and managing cover crop residues prior to sowing or planting the cash crop to maximise germination and establishment of the following cash crop (see Special topic 1). While effective organic no-till systems are still in the developmental phase, other options for reducing tillage are available, such as monitoring the soil organic matter budget to inform choices about tillage operations (see Special topic 4), strip cropping with semi-permanent beds (see Special topic 1) and using a ley phase in the crop rotation (see Special topic 4).

\section{Information technology}

Advances in information technology have created tools for recording, managing, analysing and presenting data. Various computer models and decision support systems have been used in an organic setting to explore nutrient and weed management (see Chapter 3), crop protection (see Chapter 4) and conversion impact (Halberg et al. 2005b, see also Chapter 10). Aspects of precision agriculture such as remote sensing and geographical information systems can also be adopted by organic farmers for a range of uses, such as land use planning (Gijsbers et al. 2001), improving tillage accuracy in weed management (Tillett et al. 2002, Rösch 2006) and improving fertiliser use efficiency in soil management (Goulding 2000, see also Chapter 17).

The development and use of indicators to evaluate farm performance are also relevant to organic agriculture. By monitoring farm performance, we can compare various management options and evaluate indicators over time on a farm, or make comparisons across farming systems (see Chapter 12). Numerous reports on the use of environmental and economic indicators are available (Roberts and Swinton 1996, Hendriks et al. 1997, OECD 1999, Helander and Delin 2004) and almost as many regarding the suitability and selection of indicators (Youngs et al. 1991, Eckert et al. 2000, Pannell and Glenn 2000, Bouma 2002). Indicators are used to measure a multitude of characteristics for different reasons and the users should be matched with the appropriate indicator tools. For example, farmers are more likely to use indicators that are easy to implement and interpret, are affordable, have a clear relationship to farm management practices and provide guidance for improving land management (King et al. 2000, Sulser et al. 2001, Ridley et al. 2003).

\section{Summary}

The organic movement has a range of strengths in various areas including agriculture and food production, international relations, direct marketing and process auditing. Fuelled by strong global consumer demand for ethically produced goods, the organic movement is expected to continue growing and diversifying. However, important issues need to be addressed such as balancing organic principles with commercial pressures and maintaining flexible (locally appropriate) standards and certification while also pursuing international harmonisation.

Most of the successes of the organic movement over the past decades have been achieved through the vision and enterprise of individuals and local farming groups operating without 
the support of government or agribusiness. As government and agribusiness groups are increasingly collaborating with the organic movement, it is anticipated that the beneficial impacts of organic farming systems will be further improved, and that the negative impacts will be minimised or avoided.

Organic agriculture will continue to challenge its critics as increasing numbers of successful enterprises are established in various countries. Organic proponents will also be challenged as new ethical questions emerge and the task of reviewing and improving organic farming methods is tackled. The organic movement has grown beyond its roots of farmers, growers groups and loyal consumers to a global niche industry. With new stakeholders and different stakes, the organic movement now has the opportunity to form more beneficial relationships and interact more directly with all key players in agricultural development.

\section{References}

Alexandra, J. and May, R. 2004. Australian Organic Agriculture - Prospects for Growth? Rural Industries Research and Development Corporation, Barton.

Avery, D. 1997. Saving the planet with pesticides, biotechnology and European farm reform. Brighton Crop Protection Conference - Weeds 1: 3-18.

Baker, B.P., Benbrook, C.M., Groth, E. and Lutz Benbrook, K. 2002. Pesticide residues in conventional, integrated pest management (IPM)-grown and organic foods: insights from three US data sets. Food Additives and Contaminants 19(5): 427-446.

Bouma, J. 2002. Land quality indicators of sustainable land management across scales. Agriculture, Ecosystems and Environment 88(2): 129-136.

Brimner, T.A. and Boland, G.J. 2003. A review of the non-target effects of fungi used to biologically control plant diseases. Agriculture, Ecosystems and Environment 100(1): 3-16.

Buresh, R.J., Smithson, P.C. and Hellums, D.T. 1997. Building soil phosphorus capital in Africa. In: Buresh, R.J., Sanchez, P.A. and Calhoun, F. (eds) Replenishing Soil Fertility in Africa. Soil Science Society of America/American Society of Agronomy, Madison. pp. 111-149.

Carpenter-Boggs, L., Kennedy, A.C. and Reganold, J.P. 2000a. Organic and biodynamic management: effects on soil biology. Soil Science Society of America Journal 64(5): 1651-1659.

Carpenter-Boggs, L., Reganold, J.P. and Kennedy, A.C. 2000b. Effects of biodynamic preparations on compost development. Biological Agriculture and Horticulture 17(4): 313-328.

Chen, S.-K., Edwards, C.A. and Subler, S. 2003. The influence of two agricultural biostimulants on nitrogen transformations, microbial activity, and plant growth in soil microcosms. Soil Biology and Biochemistry. 35(1): 9-19.

Clay, L. 2003. Facing up to GMO and realities. Acres Australia 11(1): 13.

Compost Tea Task Force 2004. Compost Tea Task Force Report. National Organic Standards Board, Washington DC.

Consumers Union. 2003. Consumers Union Guide to Environmental Labels. Consumers Union, Yonkers. <http://www.eco-labels.org>. Accessed 20/9/03.

Cools, N., De Pauw, E. and Deckers, J. 2003. Towards an integration of conventional land evaluation methods and farmers' soil suitability assessment: a case study in northwestern Syria. Agriculture, Ecosystems and Environment 95(1): 327-342.

Cornish, P.S. and Stewart, T.E.B. 2002. Certification - case studies with Australian market gardeners. In: Thompson, R. (ed.) Cultivating Communities. Proceedings of the 14th IFOAM Organic World Congress, 21-28 August 2002, Victoria, Canada. Canadian Organic Growers, Ottawa. p. 222.

Doing, H. 1997. The landscape as an ecosystem. Agriculture, Ecosystems and Environment 63(2-3): 221-225. 
Drinkwater, L.E., Letourneau, D.K., Workneh, F., van Bruggen, A.H.C. and Shennan, C. 1995. Fundamental differences between conventional and organic tomato agroecosystems in California. Ecological Applications 5(4): 1098-1112.

Eckert, H., Breitschuh, G. and Sauerbeck, D.R. 2000. Criteria and standards for sustainable agriculture. Journal of Plant Nutrition and Soil Science 163(4): 337-351.

Edmeades, D.C. 2003. The long-term effects of manures and fertilisers on soil productivity and quality: a review. Nutrient Cycling in Agroecosystems 66(2): 165-180.

Gijsbers, G., Janssen, W., Hambly Odame, H. and Meijerink, G. (eds) 2001. Planning Agricultural Research: A Sourcebook. CAB International, Wallingford.

Githiori, J.B., Hoglund, J., Waller, P.J. and Baker, R.L. 2003. The anthelmintic efficacy of the plant, Albizia anthelmintica, against the nematode parasites Haemonchus contortus of sheep and Heligmosomoides polygyrus of mice. Veterinary Parasitology 116(1): 23-34.

Goldstein, W.A. and Barber, W. 2005. Yield and root growth in a long-term trial with biodynamic preparation. In: Shaping Sustainable Systems. Proceedings of the 15th IFOAM Organic World Congress. 20-23 September 2005, Adelaide Australia. IFOAM (International Federation of Organic Agriculture Movements), Bonn. CD-ROM.

Gosling, P. and Shepherd, M. 2005. Long-term changes in soil fertility in organic arable farming systems in England, with particular reference to phosphorus and potassium. Agriculture, Ecosystems and Environment 105: 425-432.

Goulding, K. 2000. Nitrate leaching from arable and horticultural land. Soil Use and Management 16(4): 145-151.

Greer, L. 2002. Organic Plug and Transplant Production. Appropriate Technology Transfer for Rural Areas, Fayetteville.

Guthman, J. 2000. Agrarian Dreams: The Paradox of Organic Farming in California. University of California Press, Berkeley.

Halberg, N., Alrøe, H.F. and Kristensen, E.S. 2005a. Synthesis: perspectives for organic agriculture in a global context. In: Halberg, N., Alrøe, H.F., Knudsen, M.T. and Kristensen, E.S. (eds) Global Development of Organic Agriculture: Challenges and Promises. CAB International, Wallingford. pp. 344-368.

Halberg, N., Sulser, T.B., Høgh-Jensen, H., Rosegrant, M.W. and Knudsen, M.T. 2005b. The impact of organic farming on food security in a regional and global perspective. In: Halberg, N., Alrøe, H.F., Knudsen, M.T. and Kristensen, E.S. (eds) Global Development of Organic Agriculture: Challenges and Promises. CAB International, Wallingford. pp. 277-322.

Harris, J.A. 2003. Measurements of the soil microbial community for estimating the success of restoration. European Journal of Soil Science 54(4): 801-808.

Helander, C.A. and Delin, K. 2004. Evaluation of farming systems according to valuation indices developed within a European network on integrated and ecological arable farming systems. European Journal of Agronomy 21(2): 53-67.

Hendriks, K., Stobbelaar, D.J. and van Mansvelt, J.D. 1997. Some criteria for landscape quality applied on an organic goat farm in Gelderland, the Netherlands. Agriculture, Ecosystems and Environment 63(2-3): 185-200.

IFOAM. 2002. Final Draft 2002. Basic Standards for Organic Production and Processing. IFOAM (International Federation of Organic Agriculture Movements), Tholey-Theley, Germany.

IFOAM. 2005. International Federation of Organic Agricultural Movements Annual Report 2004. International Federation of Organic Agriculture Movements, Bonn.

Ikerd, J. 1999. Specialized systems and the economic stakes. In: Organic Agriculture Faces the Specialization of Production Systems. Jack Cartier Center, Lyon France, December 6-9, 1999. 
Ingham, R.E., Trofymow, J.A., Ingham, E.R. and Coleman, D.C. 1985. Interactions of bacteria, fungi, and their nematode grazers on nutrient cycling and plant growth. Ecological Monographs 55: 119-140.

Keatinge, R., Jackson, F., Kyriazakis, I. and Cork, S.A. 2002. Developing parasite control strategies in organic systems. In: Powell, J. (ed.) Proceedings of the UK Organic Research 2002 Conference: Research in Context. 26-28 March 2002, Aberystwyth. Organic Centre Wales, Institute of Rural Studies, University of Wales Aberystwyth, Aberystwyth. pp. 341-345.

King, C., Gunton, J., Freebairn, D., Coutts, J. and Webb, I. 2000. The sustainability indicator industry: where to from here? A focus group study to explore the potential of farmer participation in the development of indicators. Australian Journal of Experimental Agriculture 40(4): 631-642.

Kirchmann, H. and Ryan, M.H. 2004. Nutrients in organic farming - are there advantages from the exclusive use of organic manures and untreated minerals? In: Fischer, T., Turner, N., Angus, J., McIntyre, L., Robertson, M., Borrell, A. and Lloyd, D. (eds) New directions for a diverse planet. Proceedings of the 4th International Crop Science Congress. 26 Sept.-1 Oct. 2004, Brisbane, Australia. The Regional Institute, Gosford. pp. CD-ROM.

Köpke, U. 2005. Organic agriculture: maintaining old principles in a changing environment? In: IFOAM (ed.) 2005. Shaping Sustainable Systems. Proceedings of the 15th IFOAM Organic World Congress. 20-23 September 2005, Adelaide Australia. International Federation of Organic Agriculture Movements, Bonn.

Kuiper, J. 1997. Organic mixed farms in the landscape of a brook valley. How can a co-operative of organic mixed farms contribute to ecological and aesthetic qualities of a landscape? Agriculture, Ecosystems and Environment 63(2-3): 121-132.

Lampkin, N. 1990. Organic Farming. Farming Press, Ipswich.

Lieblein, G., Østergaard, E. and Francis, C. 2005. Becoming an agroecologist through action education. International Journal of Agricultural Sustainability 2(3): 147-153.

Lohr, L. 2005. Economic, social, and environmental benefits associated with US organic agriculture. In: Köpke, U., Niggli, U., Neuhoff, D., Cornish, P., Lockeretz, W. and Willer, H. (eds) Researching Sustainable Systems. Proceedings of the First Scientific Conference of the International Society of Organic Agriculture Research (ISOFAR), Held in cooperation with the International Federation of Organic Agriculture Movements (IFOAM) and the National Association for Sustainable Agriculture, Australia (NASAA). 21-23 September 2005, Adelaide Convention Centre, Adelaide, Australia. International Society of Organic Agriculture Research, Institute of Organic Agriculture and Research Institute of Organic Agriculture, Bonn and Frick. pp. 446-449.

Lotter, D.W. 2003. Organic agriculture. Journal of Sustainable Agriculture 21(4): 59-128.

Lotter, D.W., Seidel, R. and Liebhardt, W. 2003. The performance of organic and conventional cropping systems in an extreme climate year. American Journal of Alternative Agriculture 18(3): 146-154.

Mäder, P., Fließbach, A., Dubois, D., Gunst, L., Fried, P. and Niggli, U. 2002. Soil fertility and biodiversity in organic farming. Science 296(5573): 1694-1697 (and supplementary material).

Manici, L.M., Caputo, F. and Babini, V. 2004. Effect of green manure on Pythium spp. population and microbial communities in intensive cropping systems. Plant and Soil 263(1): 133-142.

Martini, E.A., Buyer, J.S., Bryant, D.C., Hartz, T.K. and Denison, R.F. 2004. Yield increases during the organic transition: improving soil quality or increasing experience? Field Crops Research 86: 255-266.

Millennium Ecosystem Assessment 2005. Millennium Ecosystem Assessment Synthesis Report. Island Press, Washington DC. 
Neeson, R. and Howell, G. 2003. National Organic Seed and Seedling Production Workshops Report. Rural Industries Research and Development Corporation, Barton.

Nyeko, P., Edwards-Jones, G., Day, R.K. and Raussen, T. 2002. Farmers' knowledge and perceptions of pests in agroforestry with particular reference to Alnus species in Kabale district, Uganda. Crop Protection 21(10): 929-941.

OECD (ed.) 1999. Environmental Indicators for Agriculture: Vol. 1: Concepts and Framework. Organisation of Economic Cooperation and Development, Paris.

Pannell, D.J. and Glenn, N.A. 2000. A framework for the economic evaluation and selection of sustainability indicators in agriculture. Ecological Economics 33(1): 135-149.

Parrott, N., Olesen, J.E. and Høgh-Jensen, H. 2005. Certified and non-certified organic farming in the developing world. In: Halberg, N., Alrøe, H.F., Knudsen, M.T. and Kristensen, E.S. (eds) Global Development of Organic Agriculture: Challenges and Promises. CAB International, Wallingford.

Pearce, B., Stopes, C., Lennartsson, M., Manchett, R., Kennedy, R. and Clarkson, J. 2000. Organic vegetable transplants: evaluation and development of production techniques. In: Alföldi, T., Lockeretz, W. and Niggli, U. (eds) IFOAM 2000 - The World Grows Organic. Proceedings of the 13th International IFOAM Scientific Conference. Convention Centre Basel, Switzerland 28 to 31 August 2000. vdf Hochschulverlag AG an der ETH Zurich, Basel. p. 198.

Pender, J. and Mertz, O. 2005. Soil fertility depletion in Sub-Saharan Africa: what is the role of organic agriculture? In: Halberg, N., Alrøe, H.F., Knudsen, M.T. and Kristensen, E.S. (eds) Global Development of Organic Agriculture: Challenges and Promises. CAB International, Wallingford.

Penfold, C. 2000. Phosphorus Management in Broadacre Organic Farming Systems. Rural Industries Research and Development Corporation, Barton.

Pretty, J., Ashby, J., Ball, A., Morison, J. and Uphoff, N. 2003. Editorial. International Journal of Agricultural Sustainability 1(1): 1-2.

Raupp, J. 1999. Biodynamic approaches in research and development. In: Zanoli, R. and Krell, R. (eds) First SREN Workshop on Research Methodologies in Organic Farming. Proceedings. Frick, Switzerland. 30 September-3 October 1998. Food and Agriculture Organization of the United Nations, Rome. pp. 41-47.

Reed, M. 2003. Servants of the Soil: The Lonely Furrow of the Soil Association 1946-2000. Centre for Rural Research, University of Exeter, Exeter.

Reganold, J.P. 1995. Soil quality and profitability of biodynamic and conventional farming systems: a review. American Journal of Alternative Agriculture 10(1): 36-45.

Ridley, A.M. 2005. The role of farming systems group approaches in achieving sustainability in Australian agriculture. Australian Journal of Experimental Agriculture 45(6): 603-615.

Ridley, A.M., Paramore, T.R., Beverly, C.R., Dunin, F.X. and Froelich, V.M.C. 2003. Developing environmental monitoring tools from sustainability indicators in the southern Riverina. Australian Journal of Experimental Agriculture 43(3): 271-284.

Roberts, W.S. and Swinton, S.M. 1996. Economic methods for comparing alternative crop production systems: a review of the literature. American Journal of Alternative Agriculture 11(1): 10-17.

Rösch, C. 2006. Using modern technologies in organic farming. Ecology and Farming 39: 45.

Ryan, M. and Ash, J. 1999. Effects of phosphorus and nitrogen on growth of pasture plants and VAM fungi in SE Australian soils with contrasting fertiliser histories (conventional and biodynamic). Agriculture, Ecosystems and Environment 73(1): 51-62.

Sena, M.M., Frighetto, R.T.S., Valarini, P.J., Tokeshi, H. and Poppi, R.J. 2002. Discrimination of management effects on soil parameters by using principal component analysis: a multivariate analysis case study. Soil and Tillage Research 67(2): 171-181. 
Sligh, M. and Christman, C. 2003. Who Owns Organic? The Global Status, Prospects and Challenges of a Changing Organic Market. Rural Advancement Foundation InternationalUSA, Pittsboro.

Steenwerth, K.L., Jackson, L.E., Calderon, F.J., Stromberg, M.R. and Scow, K.M. 2003. Soil microbial community composition and land use history in cultivated and grassland ecosystems of coastal California. Soil Biology and Biochemistry 35(3): 489-500.

Stirzaker, R., Lefroy, T., Keating, B. and Williams, J. 2000. A Revolution in Land Use: Emerging Land Use Systems for Managing Dryland Salinity. CSIRO Land and Water, Dickson.

Stoneham, G., Eigenraam, M., Ridley, A. and Barr, N. 2003. The application of sustainability concepts to Australian agriculture: an overview. Australian Journal of Experimental Agriculture 43(3): 195-203.

Sulser, T.B., Duryea, M.L., Frolich, L.M. and Guevara-Cuaspud, E. 2001. A field practical approach for assessing biophysical sustainability of alternative agricultural systems. Agricultural Systems 68(2): 113-135.

Svensson, K. and Pell, M. 2001. Soil microbial tests for discriminating between different cropping systems and fertiliser regimes. Biology and Fertility of Soils 33(2): 91-99.

Tafuna'i, A.M. 2005. Technology, tradition \& trade sustainable rural economies. In: Shaping Sustainable Systems. Proceedings of the 15th IFOAM Organic World Congress. 20-23 September 2005, Adelaide Australia. IFOAM (International Federation of Organic Agriculture Movements), Bonn. CD-ROM.

Thirsk, J. 2000. Alternative Agriculture: A History. From the Black Death to the Present Day. Oxford University Press, Oxford.

Tillett, N.D., Hague, T. and Miles, S.J. 2002. Inter-row vision guidance for mechanical weed control in sugar beet. Computers and Electronics in Agriculture 33(3): 163-177.

Tilman, D. 1999. Global environmental impacts of agricultural expansion: the need for sustainable and efficient practices. Proceedings of the National Academy of Sciences of the United States of America. 96(11): 5995-6000.

Trejo-Estrada, R., Rivas Sepulveda, I. and Crawford, D.L. 1998. In vitro and in vivo antagonism of Streptomyces violaceusniger YCED9 against fungal pathogens of turfgrass. World Journal of Microbiology and Biotechnology 14(6): 865-872.

Trenbath, B.R. 1999. Multispecies cropping systems in India: predictions of their productivity, stability, resilience and ecological sustainability. Agroforestry Systems 45(1-3): 81-107.

Trewavas, A. 2001. Urban myths of organic farming. Nature 410: 409-410.

Trewavas, A. 2004. A critical assessment of organic farming-and-food assertions with particular respect to the UK and the potential environmental benefits of no-till agriculture. Crop Protection 23(9): 757-781.

van de Ven, G.W.J., de Ridder, N., van Keulen, H. and van Ittersum, M.K. 2003. Concepts in production ecology for analysis and design of animal and plant-animal production systems. Agricultural Systems 76(2): 507-525.

Vazquez, R.I., Stinner, B.R. and McCartney, D.A. 2003. Corn and weed residue decomposition in northeast Ohio organic and conventional dairy farms. Agriculture, Ecosystems and Environment 95(2-3): 559-565.

Vereijken, J.F.H.M., van Gelder, T. and Baars, T. 1997. Nature and landscape development on organic farms. Agriculture, Ecosystems and Environment 63(2-3): 201-220.

Vogt, K.A., Beard, K.H., Hammann, S., O’ Hara Palmiotto, J., Vogt, D.J., Scatena, F.N. and Hecht, B.P. 2002. Indigenous knowledge informing management of tropical forests: the link between rhythms in plant secondary chemistry and lunar cycles. Ambio 31(6): 485-490. 
Wardle, D.A., Giller, K.E. and Barker, G.M. 1999. The regulation and functional significance of soil biodiversity in agroecosystems. In: Wood, D. and Lenné, J.M. (eds) Agrobiodiversity: Characterization, Utilization, and Management. CABI Publishing, Wallingford. pp. 87-121.

Welbaum, G.E., Sturz, A.V., Dong, Z. and Nowak, J. 2004. Managing soil microorganisms to improve productivity of agro-ecosystems. Critical Reviews in Plant Sciences 23(2): 175-193.

Welsman, S. 2001. Keeping Sheep Alive. Sustainable Control of Internal Parasites in Sheep (SCIPS) Program Review. Australian Wool Innovation, Sydney.

White, R.E. 2005. Vegetable module propagation - the transition from a conventional propagation system to organic propagation. In: International Congress on Organic Farming, Food Quality and Human Health. Newcastle upon Tyne, UK, 6-9 January 2005. University of Newcastle upon Tyne, Newcastle. <http://www.qlif.org/qlifnews/april05/con3. html\#Anchor-Vegetabl-558>. Accessed 17/1/06.

Willer, H. and Yussefi, M. (eds) 2005. The World of Organic Agriculture 2005 - Statistics and Emerging Trends. International Federation of Organic Agriculture Movements, Bonn.

Wood, S., Sebastian, K. and Scherr, S.J. 2001. Pilot Analysis of Global Ecosystems: Agroecosystems. World Resources Institute, Washington DC.

Woodward, L. and Vogtmann, H. 2004. IFOAM's Organic Principles. Ecology and Farming 36: 24-26.

Wynen, E. 2003. Organic Agriculture in Australia - Levies and Expenditure. Rural Industries Research and Development Corporation, Barton.

Youngs, G.A., Goreham, G.A. and Watt, D.L. 1991. Classifying conventional and sustainable farmers: does it matter how you measure? Journal of Sustainable Agriculture 2(2): 91-115. 